\title{
Identifying and managing common childhood language and speech impairments
}

One of the references in this Clinical Review was accidentally omitted in the published version (BMJ 2015;350:h2318, doi:10. 1136/bmj.h2318). The section that details the "age at which $90 \%$ of British children have acquired sound" was taken from a paper by Dodd B et al and this should have been cited. The full reference that should have been listed is: Dodd B, Holm A,
Hua Z, Crosbie S. Phonological development: a normative study of British English-speaking children. Clin Linguist Phon 2003;17(8):617-43.

Cite this as: BMJ 2015;350:h2851

(๑) BMJ Publishing Group Ltd 2015 